\title{
ЛІНГВІСТИЧНИЙ СЕМІОКОД СУЧАСНОЇ УКРАЇНСЬКОÏ ПОЕЗІЇ: МЕТАМОВА, ОБРАЗ, СЕНС
}

У пропонованій статті автори досліджують асоиіативно-образний та сенсотвірний потенціал тінгвістичних термінів і понять як конституентів лінгвістичної метамови, інтегрованих у поетичний контекст для творення оригінального словесного образу - конкретно-чуттєвого чи екзистениійно наснаженого. Для потреб дослідження введено поняття лінгвістичного семіокоду, а його складники потлумачено як культурні знаки, здатні кодувати відповідні сенси у вимірі авторського поетичного мовомислення. 3'ясовано, що сучасна українська поезія активно послуговується лінгвістичним семіокодом, що дозволило спрогнозувати поетичну семантику відповідних термінопонять і подати власну інтерпретацію сенсів, закладених y тексті.

Ключові слова: лінгвістичний семіокод, метамова, словесний образ, сенс поетичного тексту.

Malenko O. O., Romantsova Ya. V. Linguistic Semiocode of Contemporary Ukrainian Poetry: Metalanguage, Image, Meaning. The study of poetic text in order to decode the author's meanings and to produce his own research versions is relevant in view of the phenomenon of artistic linguistic thinking, polysemantic and verifiable in nature. The purpose of the proposed research is to investigate the associative-figurative and sensory-forming potential of linguistic terms and concepts as constituents of the linguistic metalanguage integrated into the poetic context to create an original verbal image - specifically sensory or existentially impregnated. The tasks of intelligence include the following: to define the linguistic semiocode, to identify its representatives involved in the creation of the poetic message, to determine the dominant verbal images of the linguistic code and to predict their semantics in the individual author context. Linguistic semiocode as the conceptual basis of linguistic metalanguage is represented by a corresponding lexico-semantic group, the constituents of which are universal linguistic concepts. In the measurement of this study, the components of linguistic semiocode appear as cultural signs capable of encoding the corresponding meanings. It is found that modern Ukrainian poetry is actively used by the linguistic semiocode, which allowed to clarify the semantic (poetic) transformation of the relevant terminology and to give its own interpretation of the meanings embedded in the context. The integration of linguistic semiocode into the fabric of Ukrainian poetic text has proved to be productive in creating original metaphorical images, producing ontologically valuable characteristics of language. The concept WORDS has been maximized in the studied poetic contexts. At the heart of the 
author's semantic loading of imaginative models with lexical dominance, the idea of the divine essence of the word is mostly transparent: the word is truth, the logo, the root cause. The concepts of phonetic and grammatical levels of language are found to be productive in creating metaphorical models with an actualized theme of carnal love.

Key words: linguistic semiocode, metalanguage, verbal image, meaning of poetic text.

\section{Вступ}

У центрі сучасних наукових рефлексій постає широкий лінгвістичний контекст в його різних дослідницьких площинах, напрямах, парадигмах, у його функційному, когнітивному й прагматичному вимірах. Лінгвістику сьогодні цікавлять складні питання онтології мови, iii функціоналу, дискурсивних ресурсів, власне всього, що охоплює мовленнєву діяльність людини в різних сферах приватного й соціального буття. Це сприяє виходу лінгвістики в широкий інформаційний контент, забезпечує інтелектуалізацію мовознавчого тезаурусу й галузевої метамови. Та $є$ ще одна сфера, де активно послуговуються лінгвістичними знаннями для створення конкретно-чуттєвих словесних образів і трансляції інтенційно зумовлених авторських сенсів. Йдеться, звісно, про сучасну поезію, яка рясніє мовознавчими поняттями й термінами, випробовуючи їх художній та асоціативно-образний потенціал

Як відомо, поезія є специфічною формою художнього мовомислення, організованого в особливий спосіб, де слово тяжіє до множинності значень, а відтак й індивідуальних смислових інтерпретацій, провокуючи інтелектуальну й асоціативно-образну діяльність читача (слухача) поетичного тексту. Чим незвичніше лексико-семантичне моделювання поетичного образу, чим оригінальнішими $є$ асоціації та аналогії, що формують семіотичний ряд вірша, тим більшою є розумова напруга реципієнта в декодуванні авторських смислів та образів. Семіотичний ряд у цьому контексті розуміємо як домінантний лексико-семантичний складник вербальної організації поетичного тексту, тобто систему мовно-виражальних засобів, що втілюють авторську інтенцію транслювати онтологійно ціннісні смисли через відповідні асоціативно-образні моделі.

На думку науковців (Н. Алефіренко, В. Красних, Г. Токарев та ін.), загальний зміст, покладений в основу семіотичного ряду, 
синергетизується за допомогою так званого культурного коду, що постає як «певна матриця, визначальний спосіб мислення та ідентифікації виявів буття» [Токарев, 2014: 28], як «сформована стереотипами лінгвокультурної свідомості сукупність знаків та механізмів» [Алефиренко, 2002: 61-62]. Культурний код спрямовує й зумовлює зміст та форми культурних репрезентацій у різних видах мистецтва, що дозволяє йому корелювати з такими поняттями, як простір культури, культурні знаки, культурні сенси, тезаурус культури [Савченко, 2013: 58]. Ці поняття об’єднані спільним сигніфікативним компонентом їхньої поняттєвої структури, зокрема семантикою смислу (сенсу), що врешті апелює до семіотичного простору культури, де функціонують і трансформуються відповідні знаки (коди), здатні породжувати як відому, так і нову інформацію.

\section{Методи дослідження}

Вивчення семіотичної системи поетичного тексту, функційного потенціалу вербальних знаків культури потребує комплексної методики, оскільки виходить за межі тільки лінгвістики, опираючись на науковий досвід культурології, семіотики, міфопоетики. Лінгвістичний патерн таких досліджень формують насамперед лексикологія й семасіологія в їх методологіях і методиках. Зокрема, для заглиблення в семантичну структуру слова, уналежненого до певного культурного коду, використовують метод компонентного аналізу; для виявлення сенсотвірних ресурсів мовного оточення ключового слова-образу здійснюють дистрибутивний аналіз контексту. Також продуктивними в лінгвопоетичних дослідженнях є такі методи: описовий (як механізм загального аналізу поетичного контексту, систематизації дібраного матеріалу й опису відповідних мовних одиниць); функціональний (для вивчення прагматичного потенціалу слова-поетизму); інтерпретаційно-текстовий аналіз (дослідницьке інтерпретування смислів поетичного тексту); лінгвокультурної інтерпретації (переведення поетичного змісту в площину культурних версифікацій).

\section{Результати дослідження}

До розуміння феномену культурних кодів наблизився свого часу В. Гумбольдт, синкретизуючи культуру й мову в парадигмі цілого та його частин [Гумбольдт, 1985]. Кожна конкретна мова в ії семіотичному потенціалі є виявом відповідної етнокультури, ширше - духовної 
Маленко О. О. , Романцова Я. В. Лінгвістичний семіокод сучасної української поезії: метамова, образ, сенс

енергії народу, свого роду його спадковою пам'яттю (за Ю. Лотманом), у якій закарбована інформація етноментального й етнокультурного характеру. Свою версію кореляцій культури й мови запропонував Е. Сепір, розуміючи культуру як те, «щзо робить і думає» суспільство, а мову - те, «як воно думає» [Сэпир, 1993: с. 193].

Найдавнішими й тому універсальними кодами в культурі $є$ біоморфний, анімістичний, фетишний, акціональний [Токарев, 2014: 28]. Усі ці коди представлені в мові словами на позначення відповідних об’єктів, явищ, артефактів (тобто тварин, рослин, сакральної сфери, предметів поклоніння, обрядів і дійств).

У зразках давньої словесної творчості (фольклорі) за допомогою цих кодів формуються смисли й образи, зрозумілі й розпізнавані в межах певної культури й часу. Підставою для релевантного декодування смислів у фольклорних текстах є два чинники: ментальний і семантичний. Ментальний чинник орієнтований на конкретну художню ментальність і лінгвосвідомість: у кожного народу за умов спільної семіотичної матриці є свої тлумачення культурних кодів. Так, у давньогрецькій лінгвосвідомості дуб символізує божественну силу, житло богів; у давньоримській - довголіття, плодючість; в українській - сила, міць, стійкість; в англійській - мудрість; старозаповітній - гордість, пихатість; християнській - символ Христа, стійкість віри.

Семантичний чинник реалізований у моносемії слова-символу в конкретному культурному контексті (у загальному культурному досвіді ці символи можуть бути амбівалентними). Тобто кожен читач ідентифікує смисл відповідного словообразу в межах своєї лінгвокультури й усталеної семантики. У цьому особливості давніх, традиційних для кожного конкретного етносу культурних семіокодів.

Якщо говорити про залучення до поетичної матерії нетрадиційних семіокодів, то витоки цього слід шукати в стратегіях модернізму, насамперед символізму (кінець XIX ст.), естетика якого будується на постулаті про те, що реальний світ є символічним відображенням простору певних ідей. Один із теоретиків символізму Жан Лакан вважав, що людські пристрасті, бажання, мрії, психічні й емоційні стани відображають символічний порядок, втілений і виявлений безпосередньо в слові, а текст автора $є$ реконструкцією глибинних символічних форм його свідомості [Лакан, 1997: 54]. Тож митці-модерністи 
прагнули відмовитись від семіотичних канонів традиційної образності, яка базувалася на моносемії, і віднайти нову художню мову, підпорядковану не описовим, а екзистенційним настановам, які зумовлювали й провокували семантичну безмежність слова у вимірі тексту. А оскільки слово загалом є певним символом, то в мові можливе існування численних, невичерпних за значенням, символічних смислових кодів.

Подібні лінгвософські ідеї були висловлені ще за століття до концепцій символістів Григорієм Сковородою (зокрема в праці «Діалог. Имя ему - потоп змиін» [Сковорода, 1983, с. 336-372]. Сковорода надавав слову великої ваги, розуміючи його як механізм, що дозволяє збагнути сенс речей, з яких складається Всесвіт (макрокосм), тобто як Божественне слово-логос, яке має ексформу (зовнішня форма) та інформу (внутрішня форма). І саме в інформі, на думку філософа, криються глибинні, істинні смисли, які й живлять слово. Це наблизило Сковороду до ідеї невичерпності семантичних ресурсів слова в межах сакрального тексту, яким, окрім Біблії, $є$ і поетичний твір. Ця ж ідея, що цілком відповідає канонам модерного поетичного світогляду, прозоріє і в тезі Олександра Потебні про те, що в кожному слові - безмежна «вертикаль» і «горизонталь» смислів, які зазнають актуалізації саме в образному мисленні [Потебня, 1985: 206]. Тож у межах поетичної мовної системи будь-яке слово здатне до семантичного перекодування.

Такого перекодування в текстах української сучасної поезії зазнала лінгвістична метамова як універсальний семіотичний код семантичного й синтаксичного опису мови-об'єкта [Селіванова, 2006: 323-325]. 3 огляду на загальні вимоги до метамови, лінгвістична метамова містить релевантні засоби для опису всіх рівнів мови - фонетичного, лексичного, фразеологічного, граматичного (зокрема, морфемного, морфологічного, синтаксичного), а також для опису комунікативних і прагматичних ресурсів мови-об'єкта. Тож основу лінгвістичної метамови становить лінгвістичний семіокод, репрезентантом якого $є$ відповідна лексико-семантична група, а ії конституентами - універсальні мовознавчі поняття.

Інтеграція лінгвістичного семіокоду в тканину українського поетичного тексту виявилася продуктивною у творенні автологійних та металогійних образних моделей з інтенційно зумовленим сенсом. Автологія представлена наративом, де слова вжито в їхніх узуальних 
Маленко О. О. , Романцова Я. В. Лінгвістичний семіокод сучасної української поезії: метамова, образ, сенс

значеннях для відтворення контекстних ситуацій, металогія - метафоричним наративом, що й провокує багатозначність контексту й множинність смислів.

В українській поетичній практиці лінгвістичний семіокод з його метамовою, здатною транслювати не лише раціональну наукову інформацію, а й творити емоційно наснажений контекст, багатий на оригінальні асоціативно-образні моделі, був активований наприкінці XX ст. Це була доба формування постмодерного художнього мислення, що долало мистецькі традиції, адаптуючи ментальну лінгвосвідомість до нестандартних літературних пропозицій на рівні форми й змісту. Попри всю критику низького постмодернізму з його пейоративною стилістикою, мусимо визнати художню вартість інтелектуального літературного постмодерну, розрахованого на відповідного читача - інтелектуала з високим рівнем знань. I серед цих знань особливо вартісними виявилися філологічні, оскільки більшість письменників 90-2000-х, що творили в новій мистецькій парадигмі, були за освітою філологами, тож їхня поетична мова ввібрала набутий філологічний досвід на рівні семіотичної організації тексту, а також інтертекстуальних сегментів прецедентного характеру. Задекларовану філологічну стратегію в поетичному текстотворенні розвивають і сучасники, долучаючись до формування лінгвістичного контенту в національному поетичному дискурсі.

Варто зупинитися на онтологійному підгрунті лінгвістичного семіокоду в українській постмодерній поезії, яке спирається на розуміння мови як категорії, що має власне буття, у якому перебігає й буття людини (за Хайдеггером, в оселі мови живе людина), а самість мови дорівнює іï божественному началу. Вочевидь, так розумів мову й Тарас Шевченко, про що він сказав у відомій рефлексіі: Ну що б, здавалося, слова? Слова та й голос, більш нічого. А серие б'ється, ожива, як ïx почує. Знать, од Бога, і голос иеей, і иі слова (Шевченко). Онтологійно розуміє мову й Ліна Костенко: Страшні слова, коли вони мовчать; Коли вони зненацька причаїлись, / Коли не знаєщ, з чого їх почать, / Бо всі слова були уже чиїмись (Костенко).

Надаючи мові статусу екзистенції, тобто буттєвої, метафізичної сутності, Хайдеггер виокремлював тих, хто робить буття мови відкритим, - це мислителі й поети, які забезпечують думкам їхнє словесне втілення в мовних образах, асоціаціях, аналогіях, подекуди 
незвичних, але таких, що передають глибинні, тобто екзистенційні, сенси [Хайдеггер, 1993]. Як засвідчує український поетичний досвід, семіотичним кодом, здатним втілити екзистенційність у тексті, виявився лінгвістичний. Мовознавчі поняття стали надто продуктивними для творення складних, інтелектуалізованих словесних образів, які в кожній конкретній читацькій свідомості потенційно отримують індивідуальний сенс, употужнюючи й розширюючи семантичний ресурс термінопоняття.

Щоб слово отримало певні художні достоїнства, говорив Потебня, потрібні зовнішні умови [Потебня, 1976: 304]. Цими умовами вчений вважав тих, кому адресований твір, адже саме читачі дають буття художньому твору, розуміючи силу його слів, інтерпретуючи його смисли, наповнюючи його власною інтелектуальною енергетикою. Тож свідомо обираючи певний семіокод, письменник орієнтується на ініційованого читача, який адекватно сприймає й декодує художню інформацію. 3 огляду на тексти представників української сучасної поезії, можемо реконструювати цього читача: насамперед філолог, начитаний та обізнаний, здатний до інтелектуальної рефлексії й власної інтерпретації запропонованих митцем семантично непрозорих словесних образів, зокрема й лінгвістичного характеру.

Різнопланово й насичено лінгвістичний код представлений у поезії Сергія Жадана, частково в Оксани Забужко, Костянтина Москальця, Юрка Покальчука, Юрія Андруховича, Віктора Неборака, Наталки Білоцерківець та інших. $Є$ тексти, що грунтуються саме на лінгвістичному коді, а смислове декодування цих текстів залежить уже від мовознавчої компетентності читача (наприклад, поезія Оксани Мардус).

Якщо вдаватися до створення просторової моделі лінгвістичного семіокоду в поезії, то варто обрати концентричний принцип, у центрі якого постає семантична домінанта - слово.

лексема семантичні поля орфографія

звуки голосні приголосні звукопис фонетична транскрипція склад відкритий закритий ненаголошений

мова СЛОВО літера

речення граматика текст парадигма

морфема метафора символ санскритська мова

розділові знаки знак оклику пунктуація 
Маленко О. О. , Романцова Я. В. Лінгвістичний семіокод сучасної української поезії: метамова, образ, сенс

Поняття слово (слова) зазнало в поезї максимальних смислових версифікацій і виявило вагомий потенціал самої лексеми слово щодо лексичної валентності. В основі авторського семантичного навантаження цього образу майже в усіх контекстах прозоріє ідея божественної суті слова: слово - істина, логос, першопричина: Здатність в слово, як в число, / Вписати ціле покоління (Забужко, 2013); Іще слова, вологі і сирі, / В розколі вуст ворушаться, мов глина (Забужко, 2013); істинні кажу вам слова / допоки горить звізда (Римарук, 1998); Щемна акустика міста, яка робить наші слова особливо тегкими (Жадан, 2015); Через те, що всі промовлені нами слова, / переплетені між собою, як вереснева трава (Жадан, 2015); Ісус на іконі сумирний враниі, / мовить слова - печальні, нагорні (Жадан, 2015); і змучені птахолови намагаються впіймати кожне слово (Жадан, 2015); Я закликаю усіх - пишіть слово Любов / пишіть ие слово - на стінах i бруківках на будинках і парканах (Покальчук, 2008); Усе минає залишаються слова і музика (Покальчук, 2008); стану дорогою, ти ж - подорожнім, стану пророком, ти ж - словом пророчим (Мардус, 2018). Костянтин Москалець екзистенціює слово в ознаках його вічності й безкінечності: Слово - рефлексія, / якій не буде кіния; / як неможливо знайти останнє число, так неможливо знайти останнє слово (Москалець, 1998), переводить слово з реальності в ілюзійний вимір, вважаючи іманентною ознакою слова його здатність створювати дійсність ілюзій: У слові є лише йому належні / дійсність ілюзій/ і тільки в иъьому ілюзійному середовищі/ воно існує [Москалець, 1998].

Очевидним $є$ екзистенційний модус образу слово, закладений не лише семантично в структурі поняття слово як філософської категорії (слово - логос, думка, сенс, світовий розум, світовий закон, врешті Бог), а й контекстно, завдяки сполучуваності поетизму слово з лексемами онтологійної семантики (слово - любов, Ісус, пророцтво, безкінечність, дійсність ілюзій) або ії метафоричними репрезентантами (слово - глина, тобто матерія деміургіi). У таких контекстах слово завжди перебуває в сильній позиції, формуючи образну модель, продуктивну в їі смислових верифікаціях. Послідовно активуючи лінгвістичний семіокод у власних дискурсах, поети ускладнюють і розширюють контекст поняттями літера, звук (голосний, приголосний), фонема, склад, лексема, семантичне поле, морфема, речення, розділові знаки, що органічно інтегруються в цілісний образ світу як 
мови в ії сегментах: Світ зробили зі слів, /Чорних лексем і семантичних полів (Жадан, 2015). Семантика структурності, закладена в дефініціях цих лінгвістичних понять, що належать до різних рівнів мови, уможливлює їх образне декодування: буттєвий простір так само багаторівневий, як і мова, це система відповідних елементів. При цьому автори прогнозують релевантного для адекватної текстової інтерпретації читача - лінгвіста або принаймні професійного філолога.

Найближчим семантично до слова є код мови. Поетизм мова здебільшого задіяний у творенні генітивних метафор із семантикою почуттєвості, емоційності: Мова ніжності, яку розуміють усі... (Жадан, 2018); Мово, якою я мовчу, мово дихання і плачу. Мово ліній на тихій руці (Жадан, 2018). Загалом генітивні конструкції з компонентами лінгвістичного семіокоду активно функціонують у поетичному тексті для моделювання метафори тіло як мова: граматико зчитаних передпліч (Жадан, 2018); гострі метафори твоїх ключиць; фонетична транскрипиія нашого тіла (Мардус, 2016).

Лінгвістичний код у поезії може бути матрицею для репрезентації способу авторського мислення (лінгвістичного) й форм (тобто вербальних репрезентантів) його означення. Вірш Оксани Мардус (Мардус, 2016) цьому підтвердження.

\section{Фонетична транскрипція нашого тіла}

фонетична транскрипція нашого тіла

не збігається з кількістю літер кинутих нами сміливо на вітер в осінь нерівним ключем відлетілих

і навесні не зустрінутих вчасно ненаголошених в тиші кохання хочеш черешню? солодка і рання ягідно буде сьогодні і рясно

тільки прийди і лишися край ночі кленом, каштаном чи дзбаном порожнім стану дорогою, ти ж - подорожнім, стану пророком, ти ж - словом пророчим 
та фонетичні транскрипції різні

наче дерева ранні і пізні

наче склади де відкритий/закритий

у слові 6 звуків і 7 наших літер

Творячи поетичний контекст у його лінгвістично насичених асоціативно-образних моделях, лексико-семантичну основу яких формують вузькі мовознавчі поняття, автор налаштовує читача на продукування так званих апостеріорних смислів, тобто таких, що породжуються й виникають у ході індивідуальної рецепції тексту. Ця апостеріорність $є$ результатом власної інтерпретаційної діяльності читача, тому й смисли будуть варіативними, залежними від низки екстралінгвістичних параметрів (зокрема, професійна й загальнокультурна освіченість). Проте підсвідомою основою породження апостеріорних смислів усе ж таки $є$ ментальна установка на релевантне семантичне декодування того чи того слова відповідно до його традиційного в лінгвокультурі значення - узуального чи образного (апріорний смисл). У вимірі української лінгвокультури слово мова в його смисловому навантаженні синкретично поєднало номінативну семантику (знакова система, засіб спілкування) й символьну (мова - логос, світ, ментальний код нації, Божественне начало), що розширило межі дискурсивного функціонування цього слова, зокрема в кодуванні та декодуванні буттєво сутнісних сенсів,

\section{Висновки}

У поетичному тексті як вербальній реальності лінгвістичний семіокод стає способом авторського мислення й означення глибинних екзистенцій, а онтологійна невідворотність слова, втілена Жаданом у фразі «липне до вуст почуття морфеми» (Жадан, 1998), підтверджена всією українською поезією, у вимірі якої слово постає першопричиною, початком, логосом, гармонією, любов’ю. А в мові, як у тексті, перебігає буття людини. Врешті все наше існування — це наші тексти. Про це рядки Оксани Забужко: Вихлипую свій текст - між видихом і вдихом (Забужко, 2013).

\section{ЛІТЕРАТУРА}

1. Алефиренко Н. Ф. Поэтическая энергия слова. Синергетика языка, сознания и культуры. Москва: ФЛИНТА: Наука, 2002. 394 с. 2. Гумбольдт В. фон. Язык и 
философия культуры. Москва: Прогресс, 1985. 452 с. 3. Жадан С. Пепсі: вірші. Харків: Майдан, 1998. 62 с. 4. Жадан С. Життя Марії. Книга віршів і перекладів. Чернівці: MERIDIAN CZERNOWITZ, 2015. 184 с. 5. Жадан С. Торкатись так, як торкаються книг. 2018. URL. : https://www.facebook.com/pg/serhiy.zhadan/about/?ref=page_internal. 6. Забужко О. Вірші: 1980 -2013. Київ: КОМОРА, 2013. 301 с. 7. Костенко Л. Страшні слова, коли вони мовчать. URL.: http://www.ukrcenter.com/Лiтература/Ліна-Костенко/23086/. 8. Лакан Ж. Инстанция буквы в бессознательном, или Судьба разума после Фрейда. Москва: Гнозис, 1997. 140 с. 9. Мардус О. Фонетична транскрипція нашого тіла. 2016. URL. : https://www.facebook.com/518455351633046/posts/821162988028946/. 10. Москалець К. Для троянди. Плерома: часопис з проблем культурологіï, теорії мистецтва, білософіï. Івано-Франківськ, 1998. Вип. 3. С. 201-207. 11. Покальчук Ю. Не наступайте на любов. Харків: Фоліо, 2008. 282 с. 12. Потебня А. А. Эстетика и поэтика. Москва: Искусство, 1976. 616 с. 13. Потебня О. О. Естетика і поетика слова. Київ: Мистецтво, 1985. 302 с. 14. Римарук I. Уривок із поеми та інші поезії. Плерома: часопис з проблем культурологіï, теорії мистецтва, філософії. 1998. Вип. 3. С. 170-172. 15. Савченко Л. В. Феномен етнокодів духовної культури у фразеології української мови: етимологічний та етнолінгвістичний аспекти. Сімферополь: Доля, 2013. 600 с. 16. Селіванова О. Сучасна лінгвістика: термінологічна енциклопедія. Полтава : «Довкілля К», 2006. 716 с. 17. Сковорода Г. Вірші. Пісні. Байки. Діалоги. Трактати. Притчі. Прозові переклади. Листи. К. : Наукова думка, 1983. 542 с. 18. Сэпир Э. Избранные труды по языкознанию и культурологии. Москва: Прогресс, 1993. 656 с. 19. Токарев Г. В. Введение в семиотику. Москва: Флинта: Наука, 2014. 160 с. 20. Хайдеггер М. Время и бытие: Статьи и выступления. Москва: Республика, 1993. 447 с. 21. Шевченко Т. Ну що 6, здавалося, слова. URL.: http://litopys.org.ua/shevchenko/shev227.htm.

\section{REFERENCES}

1. Alefirenko, N. F. (2002). Poeticheskaya energiya slova. Sinergetika yazyka, soznaniya $i$ kul'tury [Poetic energy of the word. Synergetics of language, consciousness and culture]. Moscow: FLINTA: Nauka [in Russian]. 2. Gumbol'dt V. fon. (1985). Yazyk i filosofiya kul'tury [Language and Philosophy of Culture]. Moskow: Progress [in Russian]. 3. Zhadan, S. (1998). Pepsi : Virshi [Pepsi: Poems]. Kharkiv: Maidan [in Ukrainian]. 4. Zhadan, S. (2015). Zhyttia Marii. Knyha virshiv i perekladiv [Life of Mary. Book of poems and translations]. Chernivtsi: MERIDIAN CZERNOWITZ [in Ukrainian]. 5. Zhadan, S. (2018). Torkatys tak, yak torkaiutsia knyh [Touch the way books touch]. Retrieved from https://www.facebook.com/ pg/serhiy.zhadan/about/?ref=page_internal [in Ukrainian]. 6. Zabuzhko, O. (2013). Virshi: 1980 [Poems: 1980]. Kyiv: KOMORA [in Ukrainian]. 7. Kostenko, L. Strashni slova, koly vony movchat [Scary words when they are silent]. Retrieved from http://www.ukrcenter.com/ Literatura/Lina-Kostenko/23086/ [in Ukrainian]. 8. Lakan, Zh. ( 1997). Instanciya bukvy $v$ bessoznatel'nom, ili Sud'ba razuma posle Freyda [The letter instance in the unconscious, or the Fate of the mind after Freud]. Moscow: Gnozis [in Russian]. 9. Mardus, O. (2016). Fonetychna transkryptsiia nashoho tila [Phonetic transcription of our body]. Retrieved from https://www.facebook.com/518455351633046/posts/821162988028946/ [in Ukrainian]. 10. Moskalets, K. (1998). Dlia troiandy. Pleroma: chasopys z problem kulturolohii, teorii mystetstva, filosofi [For the rose. Pleroma: Journal of Cultural Studies, Art Theory, Philosophy]. Ivano-Frankivsk [in Ukrainian]. 11. Pokal'chuk, Yu. (2008). Ne nastupayte na lyubov [Do 
not step on love]. Kharkiv: Folio [in Russian]. 12. Potebnya, A. A. (1976). Estetika i poetika [Aesthetics and Poetics]. Moscow: Iskusstvo [in Russian]. 13. Potebnya, O. O. (1985). Estetika i poetika slova [Aesthetics and poetics of the word]. Kyiv: Mistectvo [in Ukrainian]. 14. Rymaruk, I. (1998). Uryvok iz poemy ta inshi poezii [An excerpt from a poem and other poetry]. Pleroma: chasopys z problem kulturolohii, teorii mystetstva, filosofii - Pleroma: Journal of Cultural Studies, Art Theory, Philosophy, 3, 170-172 [in Ukrainian]. 15. Savchenko, L. V. (2013). Fenomen etnokodiv dukhovnoi kultury u frazeolohii ukrainskoi movy: etymolohichnyi ta etnolinhvistychnyi aspekty [The phenomenon of ethno-codes of spiritual culture in the phraseology of the Ukrainian language: etymological and ethno-linguistic aspects]. Simferopil: Dolia [in Ukrainian]. 16. Selivanova, O. (2006). Suchasna linhvistyka: terminolohichna entsyklopediia [Modern linguistics: a terminological encyclopedia]. Poltava: Dovkillia - K [in Ukrainian]. 17. Skovoroda, H. (1983). Virshi. Pisni. Baiky. Dialohy. Traktaty. Prytchi. Prozovi pereklady. Lysty [Poems. Songs. Fables. Dialogues. Treatises. Parables. Prose translations. Letters]. Kyiv: Naukova dumka [in Ukrainian]. 18. Sepir, E. (1993). Izbrannye trudy po yazykoznaniyu i kul'turologii [Selected Works on Linguistics and Cultural Studies]. Moscow: Progress [in Russian]. 19. Tokarev, G. V. (2014). Vvedenie v semiotiku [Introduction to Semiotics]. Moskva: Flinta: Nauka [in Russian]. 20. Haydegger, M. (1993). Vremya i bytie: Stat'i i vystupleniya [Time and Being: Articles and speeches]. Moskow: Respublika [in Russian]. 21. Shevchenko, T. Nu shcho b, zdavalosia, slova [Well, that seemed to be words]. Retrieved from http://litopys.org.ua/shevchenko/shev227.htm [in Ukrainian].

Маленко Олена Олегівна - доктор філологічних наук, професор, завідувач кафедри українознавства і лінгводидактики, Харківський національний педагогічний університет імені Г. С. Сковороди. Вул. Валентинівська, 2, Харків, 61168, Україна.

Tel.: +38 067-938-86-57

E-mail: malena-o@yandex.ua

https://orcid.org/0000-0003-4753-0036

Malenko Olena Olehivna - Doctor of Philology, Professor, Head of the Ukrainian Studies and Applied Linguistics Department, H.S. Skovoroda Kharkiv National Pedagogical University. Valentynivska Str., 2, Kharkiv, 61168, Ukraine.

Романцова Яна Володимирівна - кандидат філологічних наук, доцент, доцент кафедри іноземних мов № 1, Національний юридичний університет імені Ярослава Мудрого, вул. Пушкінська, 77, м. Харків, 61024, Україна.

Tel.: +38-063-243-17-48

E-mail: yanaromantsova@ukr.net

http://orcid.org/0000-0003-1972-9224

Romantsova Yana Volodymyrivna - PhD in Philology, Associate Professor, Foreign Language Department № 1, Yaroslav Mudryi Law University. Pushkinska Str., 77, 61024, Kharkiv, Ukraine. 